\title{
The Happy Meal ${ }^{\circledR}$ Effect: The Impact of Toy Premiums on Healthy Eating Among Children in Ontario, Canada
}

\author{
Erin P. Hobin, PhD, ${ }^{1}$ David G. Hammond, PhD, ${ }^{1}$ Samantha Daniel, BA, ${ }^{1}$ Rhona M. Hanning, PhD, ${ }^{1}$ \\ Steve R. Manske, EdD ${ }^{2}$
}

\begin{abstract}
Objectives: "Toy premiums", offered with McDonald's Happy Meals ${ }^{\circledR}$, are a prominent form of food marketing directed at children. Two California jurisdictions recently implemented policies that only permit offering fast-food toy premiums with meals that meet certain nutritional criteria. The primary objective of the current study was to examine elements of this policy in a Canadian context and determine if children select healthier food products if toy premiums are only offered with healthier food options. The study also examined if the impact of restricting toy premiums to healthier foods varied by gender and age.
\end{abstract}

Methods: A between-groups experimental study was conducted with 337 children aged 6-12 years attending day camps in Ontario, Canada. Children were offered one of four McDonald's Happy Meals ${ }^{\circledR}$ as part of the camp lunch program: two "healthier" meals that met the nutritional criteria and two meals that did not. In the control condition, all four meals were offered with a toy premium. In the intervention condition, the toy was only offered with the two "healthier" meals.

Results: Children were significantly more likely to select the healthier meals when toys were only offered with meals that met nutritional criteria $(\mathrm{OR}=3.19,95 \% \mathrm{Cl}: 1.89-5.40)$. The effect of pairing toys with healthier meals had a stronger effect on boys than girls $(\mathrm{OR}=1.90,95 \% \mathrm{Cl}: 1.14-3.17)$.

Conclusion: Policies that restrict toy premiums to food that meet nutritional criteria may promote healthier eating at fast-food restaurants.

Key words: Obesity; nutrition policy; fast foods

La traduction du résumé se trouve à la fin de l'article.

Can J Public Health 2012;103(4):e244-e248

$\mathrm{T}$ he prevalence of overweight and obesity has risen dramatically among Canadian children. Since 1981, childhood obesity rates have almost tripled, with approximately $26 \%$ of Canadians aged 6-19 years currently overweight or obese. ${ }^{1}$ Childhood obesity is an important predictor of adult obesity and significantly increases the risk of chronic disease, including diabetes and cardiovascular disease. ${ }^{2,3}$

The increasing proportion of Canadian children who eat at fastfood outlets as part of their regular diet has likely contributed to the increase in obesity. ${ }^{4}$ Food consumed at fast-food restaurants is associated with higher caloric, higher fat, and saturated fat intake, as well as lower intake of fruit and vegetables.-8 $\mathrm{A}$ recent study of the nutrient quality of children's meals available at fast-food restaurants in the US found that only $3 \%$ of available meals met nutrition criteria for school-aged children. ${ }^{9}$

Toy premiums - providing toys with children's meals - are an increasingly popular marketing practice used by the fast-food industry. ${ }^{10-12}$ In most cases, toy premiums consist of cross-promotions with the entertainment industry and feature characters from popular children's movies or TV programs. In 2006, fast-food outlets in the US spent approximately $\$ 330$ million on toy premiums with children's meals. ${ }^{13}$ More than 1.2 billion meals with toys were sold to children under age 13, making these meals the top-selling fastfood item to children. ${ }^{13}$ Comparable sales data among Canadian fast-food outlets are unavailable; however, toy premium marketing trends appear to be similar.
Currently, Canada has very few regulations restricting food marketing practices directed at children. ${ }^{14}$ Quebec is the only province to prohibit food marketing to children in schools as well as on Canadian-based television and radio advertising. ${ }^{14}$ Recently, Santa Clara and San Francisco Counties in California became the first jurisdictions in the world to regulate toy premiums provided by restaurants. ${ }^{15,16}$ The standards only allow toy premiums to be provided with meals that meet certain nutritional criteria established by the US Department of Agriculture. ${ }^{15,16}$ Since the regulations were passed, the food industry has actively lobbied state lawmakers in Florida and Arizona to pre-empt similar legislation preventing toy bans from reaching their states. ${ }^{17}$

\footnotetext{
Author Affiliations

1. School of Public Health and Health Systems, University of Waterloo, Waterloo, ON 2. Propel Centre for Population Health Impact, University of Waterloo, Waterloo, ON Correspondence: David Hammond, School of Public Health and Health Systems, University of Waterloo, 200 University Ave West, Waterloo, ON N2L 3G1, Tel: 519. 888-4567, ext. 36462, E-mail: dhammond@uwaterloo.ca

Acknowledgements of Sources of Support: We would like to thank the Chaplin Family YMCA of Cambridge for their support of this study. This research was supported by a grant from the Propel Centre for Population Health Impact at the University of Waterloo, a Post-doctoral Fellowship Award funded by the Heart and Stroke Foundation of Canada and the CIHR/Training Grant in Population Intervention for Chronic Disease Prevention: A Pan-Canadian Program (Hobin, Grant \#: 53893), a Canadian Institutes of Health Research New Investigator Award (Hammond), and a Canadian Cancer Society Research Institute Junior Investigator Research Award (Hammond).

Conflict of Interest: None to declare.

"McDonald's" and "Happy Meal" are registered trademarks of the McDonald's Corporation. "Coke" is a registered trademark of The Coca-Cola Company.
} 
Previous research has shown that children are exposed to high levels of food marketing in general ${ }^{18-22}$ and that exposure to television advertising is associated with greater preference for unhealthy foods and beverages. ${ }^{22}$ However, to our knowledge, only a single study has examined the effect of toy premiums on children's food choices. ${ }^{23}$ Results of this study suggest that children choose healthier meal options if toy premiums are only provided with healthier meals. However, the study did not examine actual meal selection or use actual examples of fast-food meals or toys available in the marketplace, and was conducted only with children age 5 years and under. As a result, there is very little evidence on the potential impact of toy premium regulations.

The primary objective of the current study was to examine whether children select healthier food products when these are accompanied by toy premiums offered by fast-food outlets in Ontario, Canada. The study also examined whether the impact of restricting toy premiums to healthier foods varied by gender and age.

\section{METHODS}

\section{Overview and design}

A between-groups experimental study was conducted with children aged 6-12 years attending a YMCA camp in Ontario. Children were offered four McDonald's Happy Meal ${ }^{\circledR}$ options as part of the lunch program at the camp: two "healthier" Happy Meal ${ }^{\circledR}$ options that met the nutritional requirements outlined in the San Francisco "Healthy Food Incentives Ordinance" and two "less healthy" Happy Meal ${ }^{\circledR}$ options that did not meet the criteria. Under the San Francisco Ordinance, children's meals accompanied by toys must be less than 600 calories with less than $35 \%$ of total calories from fat, less than $10 \%$ of calories from saturated fat, less than $0.5 \mathrm{~g}$ of trans-fat, and less than $640 \mathrm{mg}$ of sodium. ${ }^{16}$ In addition, at least $50 \%$ of bread products must be whole wheat and the meal must include at least one-half cup of fruit and of vegetables. ${ }^{16}$ The two healthier Happy Meal ${ }^{\circledR}$ options offered in this study met all of the criteria except the $50 \%$ of bread products being whole wheat. However, when the nutritional value of the McDonald's ${ }^{\circledR}$ hamburger bun and wrap are compared to the nutritional value of $100 \%$ whole wheat hamburger buns and wraps, the difference in the grams of fibre was relatively minimal (e.g., $1 \mathrm{~g}$ of fibre in McDonald's ${ }^{\circledR}$ hamburger bun compared to $2 \mathrm{~g}$ of fibre in a standard commercial 100\% whole wheat hamburger bun). ${ }^{24,25}$

Children attending the YMCA camp were randomly assigned to either a control or intervention condition according to week of camp attended. In the control condition, all four meal options were offered with a toy. In the intervention condition, the toy was only offered with the two "healthier" meals. The toy premiums offered to children varied each week according to the toys offered by McDonald's ${ }^{\circledR}$ restaurants for the study dates. During four of the six study weeks, gender-specific toys were provided, while a genderneutral toy was offered for the other two weeks.

\section{Participants and recruitment}

All children attending the YMCA camp in Ontario were invited to participate in the study. Information letters with consent forms written in English were mailed to parents one week prior to the study. The letters informed parents that their child was being invited to participate in research examining food marketing directed at children without revealing the use of toys as the stimuli. In total, $64 \%$ of chil- dren ( $n=337)$ were recruited from the camp over a 6-week period in July and August 2011. Children were randomly assigned to either the control condition or the intervention condition according to week of camp attended so that all children attending camp in the same week were assigned to the same condition. Children attending multiple weeks of camp (13\%) only participated in the study their first week of camp. The study received clearance from the Office of Research Ethics, University of Waterloo, and the parents of all study participants provided active permission prior to the study.

\section{Protocol}

On the morning of data collection, camp staff read an information letter to participating children introducing the study and what was required to participate in the study. The camp staff then provided children with a lunch meal order form. On the order form, children were asked to include their name, age, gender, and to select one of four Happy Meal ${ }^{\circledR}$ options. The four meal options included: A) McDonald's ${ }^{\circledR}$ hamburger with ketchup, pickles and two slices of onion, small French fries, and a can of Coke ${ }^{\circledR}$; B) McDonald's ${ }^{\circledR}$ grilled chicken wrap with a sodium-reduced tortilla, one-half cup of lettuce, Monterey Jack and light cheddar cheese, and sodium-reduced ranch sauce, small French fries, and a can of Coke ${ }^{\circledR}$; C) McDonald's ${ }^{\circledR}$ hamburger with ketchup, pickles, and two slices of onion, apple slices with caramel dipping sauce, and a bottle of water; and D) McDonald's ${ }^{\circledR}$ grilled chicken wrap with a sodium-reduced tortilla, one-half cup of lettuce, Monterey Jack and light cheddar cheese, and sodium-reduced ranch sauce, apple slices with caramel dipping sauce, and a bottle of water.

Order forms were designed according to the experimental condition. In the control condition, all four meal options were offered with a toy premium. A picture of the toy premium was displayed next to each meal option. In the intervention condition, the toy was only offered with the two meal options that met nutritional criteria (options $\mathrm{C}$ and $\mathrm{D}$ ). Intervention menus displayed a picture of the toy premium for options C and D, and indicated "No Toy" for options A and B (please refer to http://davidhammond.ca/downloads/Nutrition\%20Study/ for copies of menus and toy information) (Accessed July 9, 2012). Completed order forms were collected by the camp staff, sealed in an envelope, and returned to the research assistants who then purchased meals and toy premiums for consumption during the lunch hour. Training was provided to all camp staff prior to the start of the study. Camp staff were instructed to help children with order forms only as needed.

\section{Measures}

\section{Outcome Measure}

The proportion of children who ordered the "healthier" Happy Meals ${ }^{\circledR}$ (options C and D) that met nutritional criteria compared to children who ordered the "less healthy" Happy Meals ${ }^{\circledR}$ (options A and B) served as the outcome measure.

\section{Explanatory Variables}

Gender and age were assessed using the information collected on the children's order forms.

\section{Analyses}

Chi-square tests were used to examine potential differences in gender and age between intervention and control conditions to eval- 
Table 1. Characteristics of Participants by Experimental Condition

\begin{tabular}{|c|c|c|c|c|}
\hline & & Experime & al Conditions & \\
\hline & & $\begin{array}{l}\text { Control } \\
n=167 \\
\%(n)\end{array}$ & $\begin{array}{c}\text { Intervention } \\
\mathbf{n}=170 \\
\%(\mathbf{n})\end{array}$ & $\begin{array}{l}\text { Chi-square by } \\
\text { Condition }\end{array}$ \\
\hline Gender & $\begin{array}{l}\text { Male } \\
\text { Female }\end{array}$ & $\begin{array}{l}51.3(78) \\
48.1(89)\end{array}$ & $\begin{array}{l}48.7(74) \\
51.9(96)\end{array}$ & $\mathrm{x}^{2}=0.3, p=0.558$ \\
\hline Age & $\begin{array}{l}6 \\
7 \\
8 \\
9 \\
10 \\
11 \\
12\end{array}$ & $\begin{array}{l}58.2(32) \\
44.4(24) \\
62.5(35) \\
45.0(27) \\
54.8(34) \\
29.0(11) \\
35.3(6)\end{array}$ & $\begin{array}{l}41.8(23) \\
55.6(30) \\
37.5(21) \\
55.0(33) \\
45.2(28) \\
71.1(27) \\
64.7(11)\end{array}$ & $X^{2}=15.0, p=0.020$ \\
\hline
\end{tabular}

Table 2. Odds Ratios for Characteristics Associated With Choosing Healthier Meal Options Among Children Ages 6 to 12

\begin{tabular}{|c|c|c|c|c|}
\hline & & Odds Ratio* & $95 \% \mathrm{Cl}$ & p-value \\
\hline \multirow[t]{2}{*}{ Gender } & Male & 1.00 & Ref. & \\
\hline & $\begin{array}{l}\text { Female } \\
6\end{array}$ & $\begin{array}{l}1.90 \\
1.00\end{array}$ & $\begin{array}{l}\text { 1.14-3.17 } \\
\text { Ref. }\end{array}$ & 0.01 \\
\hline \multirow{6}{*}{ Age } & 7 & 0.45 & $0.20-1.03$ & 0.06 \\
\hline & 8 & 0.62 & $0.27-1.39$ & 0.24 \\
\hline & 9 & 0.27 & $0.11-0.64$ & 0.003 \\
\hline & 10 & 0.31 & $0.13-0.72$ & 0.007 \\
\hline & 11 & 0.28 & $0.11-0.73$ & 0.01 \\
\hline & 12 & 0.19 & $0.05-0.79$ & 0.02 \\
\hline \multirow[t]{2}{*}{ Condition } & Control & 1.00 & Ref. & \\
\hline & Intervention & 3.19 & $1.89-5.40$ & $<0.0001$ \\
\hline
\end{tabular}

uate whether randomly assigning different weeks of camp was effective in distributing potential confounders across experimental conditions. Logistic regression models were used to test for differences between study conditions, adjusting for age and gender. The outcome measure in the model was whether or not the child chose the healthier meal option (1) versus the less healthy meal option (0). Two-way interactions between gender and condition and age and condition were also examined. All analyses were conducted in SAS version 9.0 (Cary, NC).

\section{RESULTS}

\section{Sample characteristics}

Table 1 shows sample characteristics by condition. Overall, 167 children participated in the control condition and 170 children participated in the intervention condition. Age varied by condition, with a greater proportion of older children in the intervention condition $\left(\mathrm{X}^{2}=15.0, \mathrm{p}=0.02\right)$. There were no statistically significant differences between the two conditions by gender.

\section{Effect of toy premium on children's food choice}

As shown in Figure 1, the proportion of children who ordered healthier meals was $39.5 \%$ in the intervention condition and $19.4 \%$ in the control condition. Table 2 shows the results of a logistic regression model examining differences by experimental condition in the proportion of children who ordered a healthier meal, adjusting for age and gender. A significant main effect of condition was found, in which children in the intervention condition were significantly more likely to order a healthier meal compared to children in the control condition (OR=3.19, 95\% CI: 1.89-5.40). The children ordering the healthier meal options were also significant-

\section{Figure 1. Proportion of children who chose healthier meal} options by study condition $(n=337)$

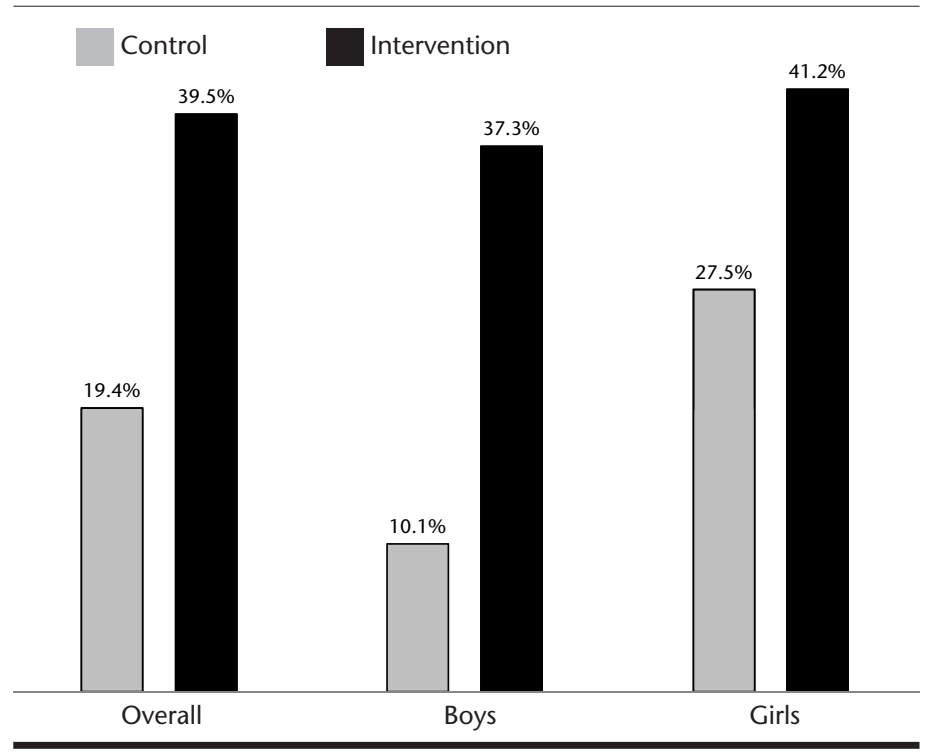

ly more likely to be female (OR=1.19, 95\% CI: 1.14-3.17). Children aged 6 years were more likely to order the healthier meal options than children aged 9-12 years when adjusting for condition. In addition, a significant two-way interaction between condition and gender $\left(\mathrm{X}^{2}=4.33, \mathrm{p}=0.038\right)$ was observed: although girls in the intervention condition were more likely to choose the healthier meal options than girls in the control condition, boys had an even greater odds of selecting healthier meals in the intervention condition than girls. Analyses were conducted to test the effect of study week by intervention and control conditions. There was a significant effect by week, however when study week was entered as a covariate in the main regression model, the pattern of findings did not change.

\section{DISCUSSION}

To our knowledge, this is the first experimental study to examine the impact of toy premiums on children's fast-food meal choices in Canada. The findings indicate that children are more likely to order healthier fast-food options if a toy is only provided with healthier options. In the current study, children were three times more likely to order the healthier meal options when toys were not offered with meals that failed to meet nutritional criteria.

Pairing toys with healthier meal options had a stronger effect on boys compared to girls. Boys were less likely to order healthier meal options than girls in the control condition, consistent with some research indicating that boys like fatty and sugary foods more than girls and that among adults, males are less likely than females to consider the nutritional content of foods they consume. ${ }^{26,27}$ The findings also suggest that the toys provided in the current study may have been more appealing to boys than girls. The toys accompanying the meals were the same toys offered by McDonalds ${ }^{\circledR}$ for that particular week. Differences in the proportion of children who selected the healthier meal across intervention weeks suggest that the influence of toy premiums to shift eating habits may depend upon the intrinsic appeal of the particular toy, which may differ across gender.

The results also suggest that children age 6 years were more likely to order the healthier meal than children ages 9-12 years. This is 
consistent with previous research stating that the diet quality of children tends to decline as they approach adolescence..$^{26,27}$ An alternative explanation specific to this study is that parents discussed meal options with children prior to camp and younger children were more apt to obey parents' requests for them to order a healthier meal option whereas older children did not obey parents' requests.

\section{Strengths and limitations}

The sample consisted of children aged 6-12 years attending a YMCA summer camp in the Waterloo Region. This convenience sample of children does not constitute a representative sample and information about the ethnicity/race of the children was not collected; however, children attending the YMCA day camp are drawn from a cross-section of socio-economic strata and ethnic groups within Cambridge, Ontario.

The overall response rate was $64 \%$ (proportion of children invited to participate who completed the study). Estimates may be biased by systematic differences between respondents and nonrespondents. In addition, participants in the intervention condition tended to be older than participants in the control condition. However, regression models were adjusted for age when testing the effect of condition. Given that the results suggest toys are less likely to influence the food choices of older children compared to younger children, the data in this analysis may underestimate the effect of toys on children's food choices.

Last, although parents were presented with study information and children may have been instructed by parents to choose the healthier meal option, ultimately the children's meal choices were made without parents being present. Future research should examine the impact of toy premiums on children's fast-food meal choices when parents are present when food is ordered, which may be more consistent with how these decisions are made in practice.

\section{Implications}

Reducing the marketing to children of foods and beverages high in fat, sugar and sodium is one of three key priorities identified by the Federal, Provincial and Territorial Framework for Action to Promote Healthy Weights. ${ }^{28}$ The current study contributes to the evidence base on food marketing and highlights a potentially effective policy measure for promoting healthier eating. Two California counties are the first jurisdictions in the world to implement such a measure and to regulate toy premiums for the purpose of promoting healthier diets. Future research should examine the impact of this policy on actual food sales and consumption.

McDonald's $^{\circledR}$ restaurants in Canada and the US recently announced nationwide changes to children's Happy Meals ${ }^{\circledR}$. Starting in the fall of 2011, McDonald's ${ }^{\circledR}$ Canada began testing Happy Meals ${ }^{\circledR}$ with a default option that includes a small serving of $1 \%$ milk fat yogurt and a smaller serving of French fries, in addition to the drink and entrée already offered. ${ }^{29}$ Overall, the new default Happy $\mathrm{Meal}^{\circledR}$ in Canada will contain fewer than 500 calories, whereas the previous Happy Meals ${ }^{\circledR}$ contained more than 570 calories. ${ }^{29}$ In the US, McDonald's ${ }^{\circledR}$ announced plans to add a half-order of apple slices and reduce the French fry serving to a half-order as the default option for all Happy Meals ${ }^{\circledR}$ starting in January 2012. ${ }^{29}$ Customers in the US will be able to request all fries or all apples if desired. The impact of these changes on meal selection and consumption is unknown.

\section{REFERENCES}

1. Tremblay M, Shields M, Laviolette M, Craig C, Janssen I, Gorber S. Fitness of Canadian children and youth: Results from the 2007-2009 Canadian Health Measures Survey. Health Rep 2010;21(1):1-15.

2. Ball G, McCargar L. Childhood obesity in Canada: A review of prevalence estimates and risk factors for cardiovascular diseases and type 2 diabetes. Can J Appl Physiol 2003;28:117-40.

3. Franks P, Hanson R, Knowler W, Sievers M, Bennett P, Looker H. Childhood obesity, other cardiovascular risk factors, and premature death. $N$ Engl J Med 2010;462(6):485-93.

4. Bowman S, Gortmaker S, Ebbeling C, Pereira M, Ludwig D. Effects of fast-food consumption on energy intake and diet quality among children in a national household survey. Pediatrics 2004;113:112-18.

5. Kant A, Graubard B. Eating out in America, 1987-2000: Trends and nutritional correlates. Prev Med 2004;38(2):243-49.

6. French S, Story M, Jeffery R. Environmental influences on eating and physical activity. Annu Rev Public Health 2001;22:309-35.

7. Satia J, Galanko J, Siega-Riz A. Eating at fast-food restaurants is associated with dietary intake, demographic, psychosocial and behavioral factors among African Americans in North Carolina. Public Health Nutr 2004;7:1089-96.

8. Schmidt M, Affenito S, Striegel-Moore R, Khoury P, Barton B, Crawford P, et al. Fast-food intake and diet quality in black and white girls: The National Heart, Lung, and Blood Institute Growth and Health Study. Arch Pediatr Adolesc Med 2005;159(7):626-31.

9. O'Donnell S, Hoerr S, Mendoza J, Goh E. Nutrient quality of fast-food kids meals. Am J Clin Nutr 2008;88:1388-95.

10. Kraak V, Pelletier D. The influence of commercialism on the food purchasing behaviour of children and teenage youth. Fam Economics Nutr Rev 1998;11:31-41.

11. Brownell K, Horgen K. Food Fight: The Inside Story of the Food Industry, America's Obesity Crisis, and What We Can Do About It. Chicago, IL: Contemporary Books, 2004.

12. Scholsser E. Fast Food Nation: The Dark Side of the All American Meal. New York, NY: HarperCollins, 2001.

13. Federal Trade Commission. Marketing food to children and adolescents: A review of industry expenditures, activities and self-regulation, 2008. Available at: http://www.ftc.gov/os/2008/07/P064504foodmktingreport.pdf (Accessed November 4, 2011).

14. Dietitians of Canada. Advertising of food and beverages to children: Position of Dietitians of Canada, December 2010. Available at: http://www.dietitians.ca/Downloadable-Content/Public/Advertising-to-Children-positionpaper.aspx (Accessed November 4, 2011).

15. Santa Clara County Board of Supervisors. An ordinance of the board of supervisors of the county of Santa Clara adding chapter XXII of division A18 to the County of Santa Clara ordinance code relating to toys and other incentives with restaurant food. Available at: http://www.sccgov.org/keyboard/attachments/BOS\%20Agenda/2010/April\%2027,\%202010/202926863/TMPKeyboard203046978.pdf (Accessed November 4, 2011).

16. San Francisco Committee/Board of Supervisors. Ordinance amending Article 8 of the San Francisco Health Code by adding Sections 471.1 through 471.8, to set nutritional standards for restaurant food sold accompanied by toys or other youth focused incentive items. Available at: http://www.sfbos.org/ $\mathrm{ftp} /$ uploadedfiles/bdsupvrs/committees/materials/lu092710_101096.pdf (Accessed November 4, 2011).

17. Bernstein S. Fast-food industry is quietly defeating Happy Meal bans. Available at: http://articles.latimes.com/2011/may/18/business/la-fi-happy-mealbacklash-20110518 (Accessed November 4, 2011).

18. Elliott C. Assessing "fun foods": Nutritional content and analysis of supermarket foods targeted at children. Obes Rev 2008;9(4):368-77.

19. Harris J, Pomeranz J, Lobstein T, Brownell K. A crisis in the marketplace: How food marketing contributes to childhood obesity and what can be done. Annu Rev Public Health 2009a;30:211-25.

20. Harris J, Schwartz M, Brownell K. Marketing foods to children and adolescents: Licensed characters and other promotions on packaged foods in the supermarket. Public Health Nutr 2009b;13(3):409-17.

21. Kovacic W, Harbour J, Leibowitz J, Rosch J. Marketing Food to Children and Adolescents: A Review of Industry Expenditures, Activities, and Self-Regulation. Washington, DC: FTC, 2008.

22. Institute of Medicine. Food Marketing to Children and Youth: Threat or Opportunity? Washington, DC: The National Academies Press, 2006.

23. McAlister A, Cornwell T. Collectible toys as marketing tools: Understanding preschool children's responses to foods. I Public Policy Marketing 2011;doi: 10.1509/jppm.10.0197

24. Plain hamburger bun McDonald's. Available at: http://www.livestrong.com/ thedailyplate/nutrition-calories/food/mcdonalds/plain-hamburger-bun/ (Accessed November 4, 2011).

25. $100 \%$ Wonder Whole Wheat Wraps. Available at: http://www.livestrong.com/ thedailyplate/nutrition-calories/food/wonder-bread/10025-whole-wheatwraps/ (Accessed November 4, 2011).

26. Golley R, Hendrie G, McNaughton S. Scores on the dietary guidelines index for children and adolescents are associated with nutrient intake and socioeconomic position. I Nutr 2011;141:1340-47. 
27. Rasmussen M, Krolner R, Klepp K, Lytle L, Brug J, Bere E, Due P. Determinants of fruit and vegetable consumption among children and adolescents: A review of the literature. Part I: Quantitative studies. Int J Behav Nutr Phys Act 2006;3(22).

28. Public Health Agency of Canada. Curbing childhood obesity: Federal, Provincial and Territorial framework for action to promote healthy weights. Available at: http://www.phac-aspc.gc.ca/hp-ps/hl-mvs/framework-cadre/pdf/ ccofw-eng.pdf (Accessed November 4, 2011).

29. CTV News. McDonald's Happy Meals changing in US, Canada. Available at: http://www.ctv.ca/CTVNews/Health/20110726/mcdonalds-apples-happymeal-110726/C (Accessed November 4, 2011).

Received: January 3, 2012

Accepted: April 28, 2012

\section{RÉSUMÉ}

Objectifs : Les jouets offerts en prime avec les repas Joyeux Festin ${ }^{\circledR}$ de McDonald sont une forme évidente de marketing alimentaire destiné directement aux enfants. Deux municipalités californiennes ont appliqué récemment des politiques qui interdisent d'offrir des jouets en prime, en restauration rapide, sauf avec des repas respectant certains critères nutritionnels. L'objectif principal de notre étude était d'examiner les éléments d'une telle politique dans le contexte canadien et de déterminer si les enfants choisissent des produits alimentaires plus sains si les jouets ne sont offerts qu'avec des options alimentaires plus saines. Nous avons aussi cherché à déterminer si les effets de la restriction des primes aux aliments plus sains variaient selon le sexe et l'âge des enfants.

Méthode : Une étude expérimentale intergroupe a été menée auprès de 337 enfants de 6 à 12 ans fréquentant des camps de jour en Ontario, au Canada. On leur a proposé l'un de quatre repas Joyeux Festin ${ }^{\circledR}$ de McDonald dans le cadre du programme de déjeuner du camp : deux repas « plus sains » respectant les critères nutritionnels et deux repas ne respectant pas ces critères. Dans le groupe témoin, on a proposé les quatre repas avec un jouet en prime. Dans le groupe expérimental, le jouet n'a été proposé qu'avec les deux repas «plus sains ».

Résultats : Les enfants ont eu significativement plus tendance à sélectionner les repas plus sains lorsque l'on n'offrait des jouets qu'avec les repas respectant les critères nutritionnels $(\mathrm{RC}=3,19$, IC de $95 \%$ : $1,89-5,40)$. L'association des jouets avec des repas plus sains exerçait un effet plus prononcé sur les garçons que sur les filles $(R C=1,90, I C$ de $95 \%$ : 1,14-3,17).

Conclusion : Les politiques qui restreignent l'offre de jouets en prime aux aliments qui respectent des critères nutritionnels peuvent favoriser une alimentation plus saine dans les restaurants rapides.

Mots clés : obésité; politique nutritionnelle; aliments de restauration rapide 